\title{
Meadow Forage Production as Influenced by Fertilization in a Dry Year
}

\author{
F.B. GOMM
}

\author{
Abstract
}

During drought years, stream flow is often insufficient to irrigate normally flooded native meadows. Herbage production of the meadow is reduced, haying operations are suspended, and the available forage is grazed by cattle. Fertilization of meadows in eastern Oregon is done in the late fall or early spring before the availability of irrigation water for the following growing season is known. This study was initiated in 1977 , following a severe winter drought, to determine the effect of fertilizing meadows in a dry year. Urea fertilizer was applied at 13 rates (0 to $745 \mathrm{~kg} \mathrm{~N} / \mathrm{ha}$ ). Maximum forage production of $1,000 \mathrm{~kg} / \mathrm{ha}$ occurred about midJuly for the check treatment. Production was not increased at fertilizer rates of 0 to $50 \mathrm{~kg} \mathrm{~N} / \mathrm{ha}$, but were increased up to 1,600 $\mathrm{kg}$ at fertilizer rates of 95 to $745 \mathrm{~kg} \mathrm{~N} / \mathrm{ha}$. Crude protein concentrations in the forage were similar to those measured in years of normal rainfall. Herbage $\mathrm{NO}_{3}-\mathrm{N}$ levels were considered nontoxic at fertilizer rates less than $540 \mathrm{~kg} \mathrm{~N} / \mathrm{ha}$. It appears that during years of low precipitation, with customary rates of fertilization (90-110 $\mathrm{kg} \mathrm{N} / \mathrm{ha}$ ), forage production will be increased slightly, forage quality will be about normal, and the danger of nitrate poisoning will be nil.

The vegetation community of seasonally flooded meadows in eastern Oregon evolved concomittently with extended annual periods of flooding. Meadow plants generally require that the soil be saturated or shallowly ponded most of the growing season. Forage yiclds are strongly influenced by the seasonal period and duration of flooding. Rumburg and Sawyer (1965) determined that yields increased as length of flooding increased except when the water depth was greater than $18 \mathrm{~cm}$. Forage yields were influenced more by the length than the period of flooding. An excessive length of flooding increased rushes and sedges and decreased yields of grasses.

During drought years such as 1977 , stream flow may be sufficient to irrigate only a small part of the meadowland in eastern Oregon. Herbage production, for the most part, is too low to justify the expense of haying operations, and the limited amount of forage produced is grazed by cattle as they are removed from range when that source of forage is depleted.

Although not specifically documented, it has been suspected that forage produced on meadows is further reduced by applying fertilizer, but the crude protein concentration may be higher than when it is produced under normal flooded conditions.

The purpose of this study was to determine the effects of applying fertilizer to meadowlands on the yield, crude protein, and potential nitrate danger to livestock of forage produced in a dry year.

\section{Methods and Procedure}

Urea $(46 \% \mathrm{~N})$ was applied April 29, 1977, to native meadow-

Author is range scientist, USDA, Agr. Res. Serv., Crops Research Lab., Utah State University, Logan 84322, formerly at Oregon State University, Squaw Butte, Agr. Exp. Sta., Burns 97720.

This article represents cooperative investigations of the USDA, Agr. Res. Serv., and the Agr. Exp. Sta., Oregon State University. Tech. Pap. No. 5465 of the latter.

Manuscript received October 24, 1980. lands of the Squaw Butte Experiment Station, located about $10 \mathrm{~km}$ southeast of Burns, Ore. Fertilizer at 13 rates, ranging from 0 to $745 \mathrm{~kg} \mathrm{~N} / \mathrm{ha}$, was applied in strips $10 \mathrm{~m}$ wide using a tractormounted broadcaster. The design provided 10 replicated plots of each treatment.

The study site, characterized as high cold desert, averages about $30 \mathrm{~cm}$ precipitation annually, of which $6 \mathrm{~cm}$ occurs during the growing season. The soil, tentatively classified as Silvies seriesFluventic and Cumulic Haplaquolls, was developed from lacustrine sediments. The vegetation was typical of wild flood meadow. Dominant plant species were Baltic rush (Juncus balticus Willd.), slender sedge (Carex praegracilis W. Boott), Nebraska sedge (Carex nebraskensis Dewey) with varying amounts of Nevada bluegrass (Poa nevadensis Vasey ex Scribn.), and beardless wildrye (Elymus triticoides Buck.). Average production of the native meadow is about 1.7 metric ton/ha.

At weekly intervals, May-August 12, several whole plant samples of the meadow forage were taken randomly from each plot. These samples were later analyzed for crude protein. On June 16, July 15 , and August 12 , two $\mathrm{m}^{2}$ samples were harvested near the center of each plot. Harvests taken subsequent to June 16 were collected from areas not harvested previously. Samples were dried at $65^{\circ} \mathrm{C}$ for 48 hours, weighed, ground, and analyzed for total nitrogen (crude protein) and nitrate-N. Analyses for crude protein were by the standard Kjeldahl method, and analyses for $\mathrm{NO}_{3}-\mathrm{N}$ followed the micro-Kjedahl method of Bremner and Edwards (1965) as modified for plant samples by the Soil Testing Laboratory of Oregon State University.

Soil samples to $15-\mathrm{cm}$ depths were taken from the 0 to $385 \mathrm{~kg}$ $\mathrm{N} /$ ha treatments at about 2-week intervals, May 13-August 15. These were dried at $100^{\circ} \mathrm{C}$ for 24 hours to determine soil moisture percentage. Air-dried samples were analyzed for $\mathrm{NO}_{3}$ and $\mathbf{N H}_{4}$. Analyses followed the micro-Kjedahl methods of Bremner and Edwards (1965).

\section{Results and Discussion}

Previous to applying fertilizer, southeastern Oregon had experienced one of its most severe winter droughts. From October 1, 1976 , to May 1, 1977, only $2.5 \mathrm{~cm}$ of precipitation had occurred (Gomm 1979). Subsequent precipitation was $5.1 \mathrm{~cm}$ in May, $1.5 \mathrm{~cm}$ in June, and $0.5 \mathrm{~cm}$ in July. The May precipitation was not sufficient to provide flood water to the meadow but benefited early growth. Plant growth commenced with the spring moisture; however, considerable variability occurred within plots due to microrelief and uneven distribution of soil moisture.

\section{Soil Analyses}

As the season progressed, the soil moisture generally declined from $67 \%$ on May 13 to $42 \%$ on June 21 and $25 \%$ on August 15 without response to fertilizer treatments.

Soil $\mathrm{N}$ levels were highest as $\mathbf{N H}_{4}$ early in the season, and the $\mathrm{NH}_{4}$ levels generally increased as the fertilizer rates increased (Fig. 1). By the end of May ( 1 month after application), there were no significant differences among rates less than $95 \mathrm{~kg} \mathrm{~N} /$ ha. At rates 

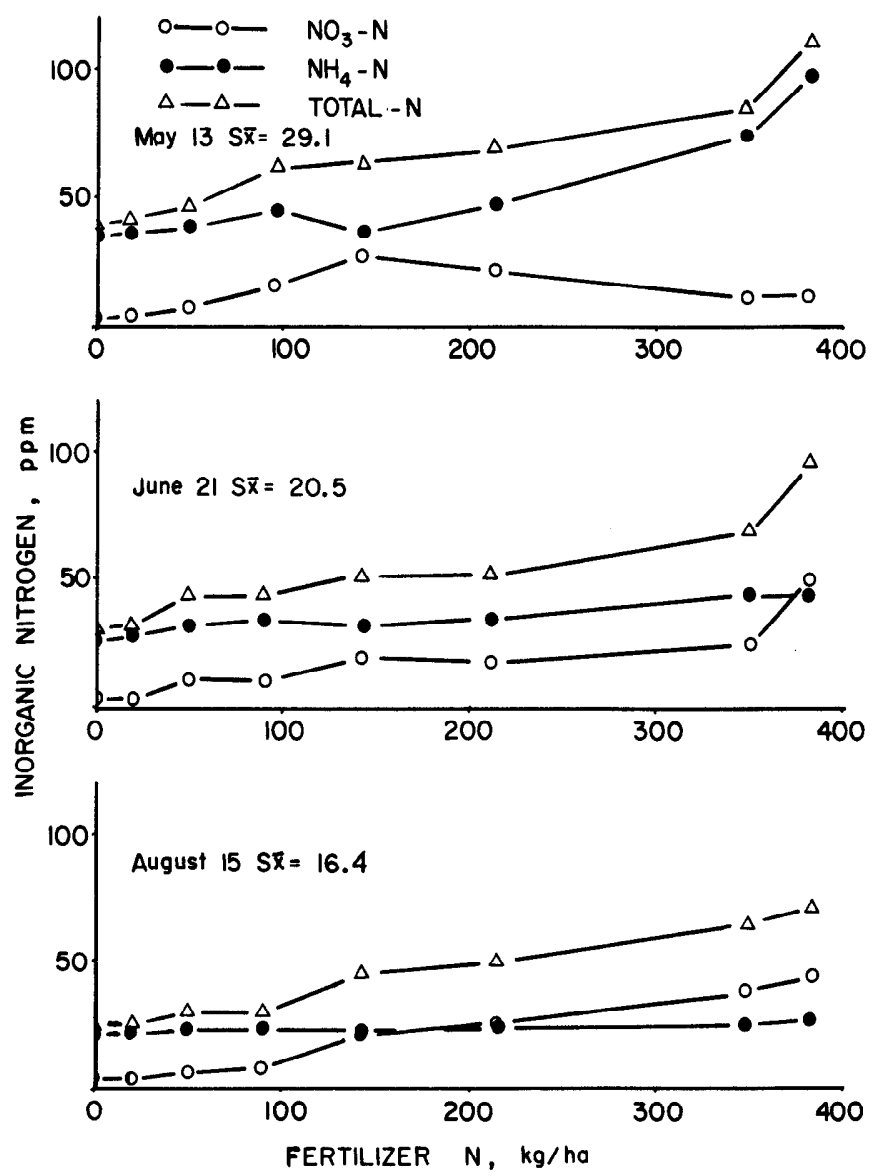

Fig. 1. Inorganic nitrogen in meadow soil at beginning, middle, and end of growing season as affected by fertilizer rates.

of $145 \mathrm{~kg} \mathrm{~N} /$ ha and larger, the concentration of $\mathrm{NH}_{4}$ in the soil increased during June due to increased application rates, but the increase with increased rate became smaller as the season progressed.

Concentrations of $\mathrm{NO}_{3}$ in the soil increased slightly at rates less than $95 \mathrm{~kg} \mathrm{~N} /$ ha but became significant components of the total available $\mathrm{N}$ when applied at rates above $95 \mathrm{~kg} /$ ha. After mid-June, the $\mathrm{NO}_{3}$ fraction became the dominant source of $\mathrm{N}$ only at the 385 $\mathrm{kg} \mathrm{N} /$ ha rate, but by August 15, $\mathrm{NO}_{3}$ was the major source of $\mathrm{N}$ at fertilizer rates above $145 \mathrm{~kg} \mathrm{~N} /$ ha. Apparently, much of the inorganic $\mathrm{N}$ was converted from $\mathrm{NH}_{4}$ to $\mathrm{NO}_{3}$ as mineralization progressed.

Total inorganic- $\mathrm{N}$ at each sampling date increased as rate of application increased, but it consistently declined as the season progressed.

\section{Forage Yield}

By mid-June, the unfertilized plants produced about $800 \mathrm{~kg} / \mathrm{ha}$, less than one-half of the production of a normal year (Fig. 2). The application of fertilizer at rates of 0 to $50 \mathrm{~kg} \mathrm{~N} /$ ha had no stimulating effect on production. However, at rates of $\mathbf{N}$ greater than 95 $\mathrm{kg} / \mathrm{ha}$, yields tended to increase with increased rate of application.

As the season progressed, yields increased until July 15, after which they decreased. The rate of decrease was greatest from applications below $350 \mathrm{~kg} \mathrm{~N} / \mathrm{ha}$. It appeared that at rates above $490 \mathrm{~kg} \mathrm{~N} / \mathrm{ha}$, the soil moisture became depleted about mid-June, and production declined rapidly after July 15 .

Precipitation during May was apparently sufficient to stimulate growth and forage production, and the application of nitrogen increased the water use efficiency of the meadow plants. It has been observed, however, that plants fertilized with $\mathrm{N}$ grow most rapidly in the spring. Grable et al. (1966) suggested that $\mathrm{N}$-fertilizer might significantly increase the evapotranspiration of plants in the spring

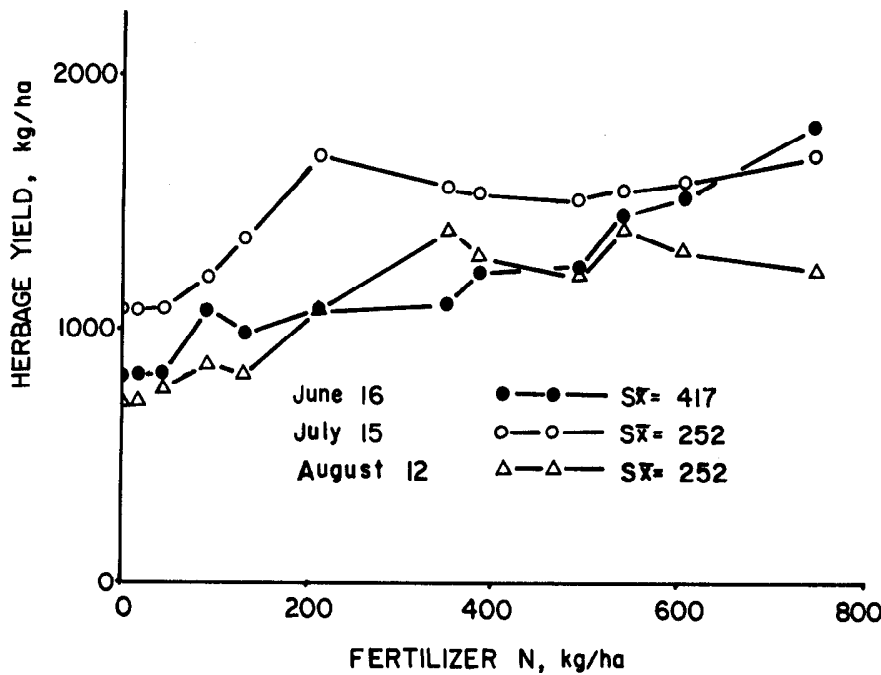

Fig. 2. Yield of meadow forage as affected by fertilizer rates at three harvest dates.

by promoting earlier growth-especially during periods of great heat transfer. It has also been shown that fertilization increases the efficiency of water usage during plant growth (Viets 1962). Kramer (1969) and Viets (1962) suggested that methods which encourage the production of dry matter increase efficiency of water usage, but they may be unprofitable. It is very probable that had the rainfall in May been less, the meadow plants would have depleted the soil moisture much earlier in the season. The stimulation of growth by the fertilizer nitrogen could have caused the depletion to occur earlier as the rates of fertilization increased. Pesek et al. (1955) suggested that small decreases in yields can be caused by fertilization. Such decreases usually occur when increased fertilizer results in large amounts of growth early in the season. Plants literally run out of water, mature, and are not able to effectively utilize later rains as are smaller and less mature plants.

The degree of water stress and the plant growth stage during which the stress occurs will variably affect net photosynthetic and respiration rates (Murata and Iyama 1963). The photosynthetic rate, however, decreases much more rapidly than respiration, resulting in reduced production. Generally, $\mathbf{N}$ applied at low to moderate rates increases dry matter production and carbohydrate reserves in roots. Nitrogen applied at high rates tends to decrease root reserves (Adegbola and McKell 1966). Consequently, when plants are stressed by lack of soil moisture, added nitrogen could cause reduction in herbage production.

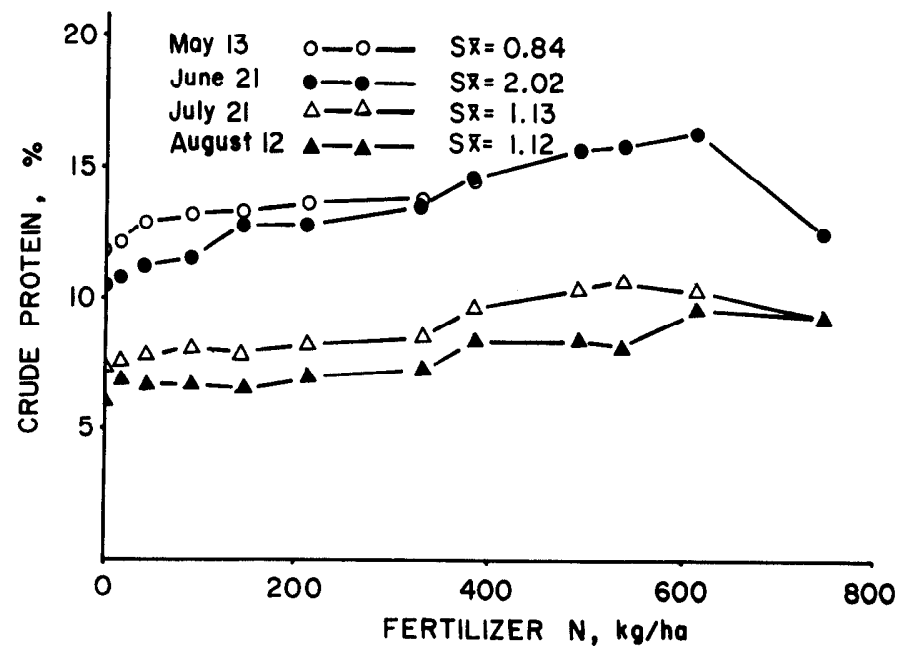

Fig. 3. Crude protein concentration in meadow forage as affected by fertilizer rates. Treatments above $385 \mathrm{~kg} \mathrm{~N} /$ ha were not sampled May 13. 


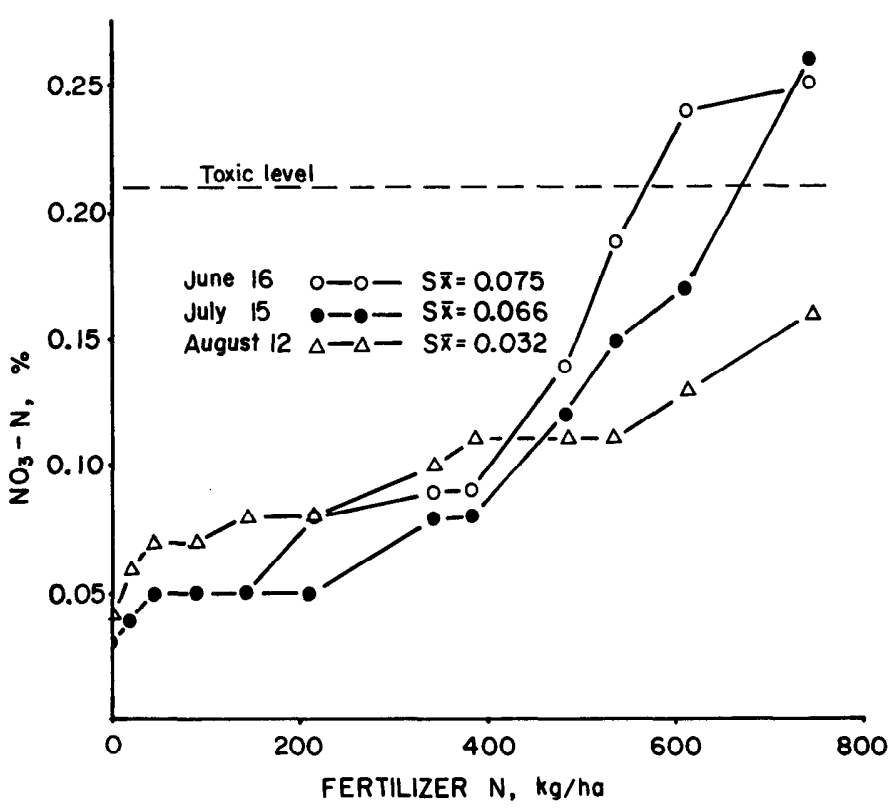

Fig. 4. Nitrate concentration in meadow forage as affected at three harvest dates by fertilizing in a dry year.

The concentration of crude protein in the forage during 1977 (Fig. 3) was no greater than would be expected in a normal year. Crude protein values during 1977 were similar to similar dates in 1962 (stream flow $85 \%$ of normal) and 1 to $2 \%$ higher than those in 1961 (stream flow 54\% of normal) (Raleigh et al. 1964). Raleigh et al. (1964) states that differences between years are often greater than differences among dates. They concluded that the length, time, and depth of flooding, and other environmental factors affect the quality of meadow forage. These factors cause changes in species which in turn contributed to forage quality in relation to date of growth. Their observations are consistent with an observation made May 27, 1977; the crude protein concentrations of component species were: beardless wildrye $21.2 \%$, Nevada bluegrass $17.7 \%$, slender sedge $14.6 \%$, Baltic rush $11.1 \%$, and Nebraska sedge $10.6 \%$. Conditions which would cause increased sedge or reduced grass would ultimately dilute the level of crude protein in the forage.

At fertilizer rates usually applied on flood meadows $(90-110 \mathrm{~kg}$ $\mathrm{N} /$ ha), the danger of nitrate poisoning from feeding or grazing was nil (Fig. 4). Although $\mathrm{NO}_{3}$ concentrations generally increased with increased fertilizer rates, the increase was minimal at rates of 0 to $385 \mathrm{~kg} \mathrm{~N} /$ ha. At higher rates, significant levels of $\mathrm{NO}_{3}$ accumulated. Forage samples harvested June 16 were considered unsafe $\left(0.21 \% \mathrm{NO}_{3}-\mathrm{N}\right)$ from $540 \mathrm{~kg} \mathrm{~N} /$ ha treatments. By August 12 , none of the fertilizer rates resulted in toxic levels of nitrate. Fertilizer treatments that caused high accumulations of nitrate were also the treatments which depleted soil moisture early in the season as indicated by herbage yields (Fig. 2). It is known that environmental conditions which cause physiological stress can cause nitrate to accumulate in plant tissues (McKee 1962). Although $\mathrm{NO}_{3}$ did not accumulate to high levels in plants fertilized at the lower rates of $\mathrm{N}$, it is quite possible they would have if the May precipitation has been less.

\section{Conclusion}

Forage production of native meadow species will be reduced when irrigation water is not available or withheld. The extent of reduced production will depend on natural precipitation, its distribution during the growing season, and the availability of soil nutrients. The heavy rainfall in May 1977 was probably the most important factor which allowed the plants to produce. Applications of nitrogen fertilizer also contributed to plant growth and increased the efficiency of water use; however, the value of increased forage due to fertilization may not have been profitable.

With the soil moisture available only from natural precipitation, the crude protein concentration in the forage was no higher than it had been reported for similar meadow forage by dates in a normal precipitation year. Fhis does not preclude the possibility that the forage quality in a dry year could be higher than that grown in a normal year. The quality of forage is highly related to seasonal growth, maturity, soil nutrients, and availability of soil moisture.

Although high rates of fertilization can cause nitrate to accumulate, it is unlikely that nitrate poisoning of livestock would occur when the forage species of eastern Oregon meadows are fertilized at customary rates $(90-110 \mathrm{~kg} \mathrm{~N} / \mathrm{ha})$. The possibility of nitrate accumulation, however, is increased early in the season when heavily fertilized plants run out of water.

\section{Literature Cited}

Adegbola, A.A., and C.M. McKell. 1966. Regrowth potential of coastal bermudagrass as related to previous nitrogen fertilization. Agron. J. $58: 145-146$.

Bremner, J.M., and A.P. Edwards. 1965. Determination and isotope-ratio analysis of different forms of nitrogen in soils. Soil Sci. Soc. Amer. Proc. 29:504-507.

Gomm, F.B. 1979. Climate and agriculture of Malheur-Harney Basin, Oregon. Oregon Agr. Exp. Sta. Special Rep. 530.

Grable, A.R., R.J. Hanks, F.J. Willhite, and H.R.Haise. 1966. Influence of fertilization and altitude on energy budgets for native meadows. Agron. J. 58:234-237.

Kramer, P.J. 1969. Plant and soil water relationships. McGraw-Hill Book Co. New York.

McKee, H.S. 1962. Nitrogen metabolism in plants. Oxford Univ. Press. Lond on and York.

Murata, Y., and J. Iyama. 1963. Crop Sci. Soc. Japan Proc. 31:315-322. (cited by White, L.M. 1974. Carbohydrate reserves of grasses: a review.) J. Range Manage. 26:13-18.

Pesek, J., R. Nicholson, and C. Spies. 1955. What about fertilizers in dry years. Iowa Farm Sci. 9:3-6.

Raleigh, R.J., C.B. Rumburg, and J.D. Wallace. 1964. Digestibility of native flood meadow hay at different stages of growth. West. Sec. Amer. Soc. Anim. Sci. Proc. 15:LV1-1-LV1-3.

Rumburg, C.B., and W.A. Sawyer. 1965. Response of wet-meadow vegetation to length and depth of surface water from wild-flood irrigation. Agron. J. 57:245-247.

Viets, F.G., Jr. 1962. Fertilizers and the efficient use of water. Advan. Agron. 14:223-264. 